\title{
Biosurfactant Production by Marine Actinomycetes Isolates Streptomyces althioticus RG3 and Streptomyces californicus RG8 as Promising Sources of Antimicrobial and Antifouling Effects
}

\author{
Moaz M. Hamed ${ }^{1 *}$, Mohamed A.A. Abdrabo ${ }^{1}$, and Asmaa M. Youssif ${ }^{2}$ \\ ${ }^{1}$ Marine Microbiology Laboratory, Marine Environmental Division, National Institute of Oceanography and Fisheries, Egypt (NIOF) \\ ${ }^{2}$ Department of Botany and Microbiology, Faculty of Science, Alexandria University, Egypt
}

Received: June 11, 2021 / Revised: August 20, 2021 / Accepted: September 15, 2021

\begin{abstract}
Two marine actinobacterial isolates, RG3 and RG8, were identified using 16Sr DNA as Streptomyces althioticus RG3 and Streptomyces californicus RG8 and submitted to the database of genetic information with accession numbers MW661230 and MW661234, respectively; they were found to have emulsification indexes of $60 \pm 2.5 \%$ and $53 \pm 2.2 \%$, respectively. The biosurfactants obtained were stable at a temperature of $35{ }^{\circ} \mathrm{C}$ for both strains; they were stable at $10 \% \mathrm{NaCl}$, in the case of $S$. althioticus $\mathrm{RG} 3$ and at $10-15 \% \mathrm{NaCl}$ in the case of Str. californicus RG8; both strains produced the most biosurfactant when exposed to alkaline conditions. We characterized the biosurfactants, including features such as their chemical composition, using Fourier transform infrared spectroscopy analysis. The antimicrobial activity of the biosurfactant extracts was evaluated using the well diffusion method against Vibrio alginolyticus MK170250, Escherichia coli ATCC 8739, Pseudomonas aeruginosa ATCC 4027, and Staphylococcus aureus ATCC 25923. S. althioticus RG3 biosurfactants were found to have better antimicrobial activity than those of Str. californicus RG8, indicating that they may be used in pharmaceutical industries and in the manufacture of antifouling products.
\end{abstract}

Keywords: Biosurfactants, actinomycetes, antimicrobial, red Sea, Egypt

\section{Introduction}

Surfactants help to form stable gels and foams by reducing surface tension at phase interfaces, emulsifying oil in water and water in oil mixtures [1]. Synthetic precursors from the petrochemical and/or oleochemical industries can be used to make these amphiphilic compounds; however, surfactants can be produced by microbial organisms in a variety of forms. Biosurfactants and bioemulsiers are surface- compounds that are active derived from sources biological such as yeasts, bacteria,

*Corresponding author

Tel.: +201101109595

E-mail: Moaz-micro@hotmail.com and yeasts [2]. Microbial surface-active compounds' molecular structure is used to classify them. Compounds with a lower molecular weight known as biosurfactants include glycolipids such as rhamnolipids, sophorolipids, mannosylerythritol lipids, and trehalose lipids, as well as lipopeptides like surfactant and fengycin [3]. High and low molecular weight surface active compounds may be utilised in a broad range of utilizations comprising treatments for individuals and at home; chemicals used in agriculture; improved recuperation of microbials from oil; textiles and biomedicines. Bio-factants and bioemulsifiers are an alternative to synthetically produced surfactants because of their low toxic, biodegradable content and an increased consumer awareness of sus- 
tainability and environmental protection [4]. Actinobacteria are members of the order Actinomycetales. Actinomycetes with characteristic filaments are grampositive bacteria. Actinomycetes encompass a wide variety of habitats. They are present in different soil types, marine and ground water, and ecosystems of mangrove [5]. They can be alkali- and thermophilic [6], halophilic [7], or acidophilic [8]. Due to their ability to produce metabolite combinations that differ in structure and function, they played a significant position in several industries. The quest for metabolites of actinomycetes is made possible by exploration of certain areas, unique ecosystems and combinations of isolation methods [9]. Surfactants, active metabolites that reduce surface tension, are thought to be formed by the majority of microorganisms, including actinomycetes. Because of the ability of their bioactive metabolites production, many researchers were attracted to investigate and isolating marine actinomycetes from unique location with a unique environment. Information on antimicrobial activity and antifouling agents by Streptomyces sp. from the Ras Garib area, Gulf of Suez, Egypt is limited. One of the metabolites produced by the actinomycetes was biosurfactant. This paper describes the possibility of marine actinomycetes isolates for the production of biosurfactants, in addition to the possibility of using it as antimicrobial and antifouling agents.

\section{Materials and Methods}

\section{Sampling and isolation of marine actinomycetes}

In sterile plastic bags, samples of marine sediment were obtained from Ras Garib area of the Gulf of Suez in Egypt (latitude $28^{\circ} 21^{\prime} 35^{\prime \prime N}$ and longitudes $033^{\circ} 04^{\prime} 39^{\prime \prime} \mathrm{E}$ ) (Fig. 1). The coordinates and map work were obtained at the Marine Physics Laboratory, (NIOF), Red Sea, using the Surfer program version 15.2.305. This sediment sample was found to be high in oils and was therefore used to monitor for actinomycetes containing biosurfactants. A dry heating method was used to isolate actinomycetes. For eight days, sediment samples were dried in a $70^{\circ} \mathrm{C}$ oven (MRC laboratory oven S36, UK), then mashed and filtered through a $1-5 \mathrm{~mm}$ sieve (AS 200 Control R-etsch Haan, Germany). The samples were shaken for two minutes and then left for one minute before being suspended in nine $\mathrm{ml}$ of sterilized seawater

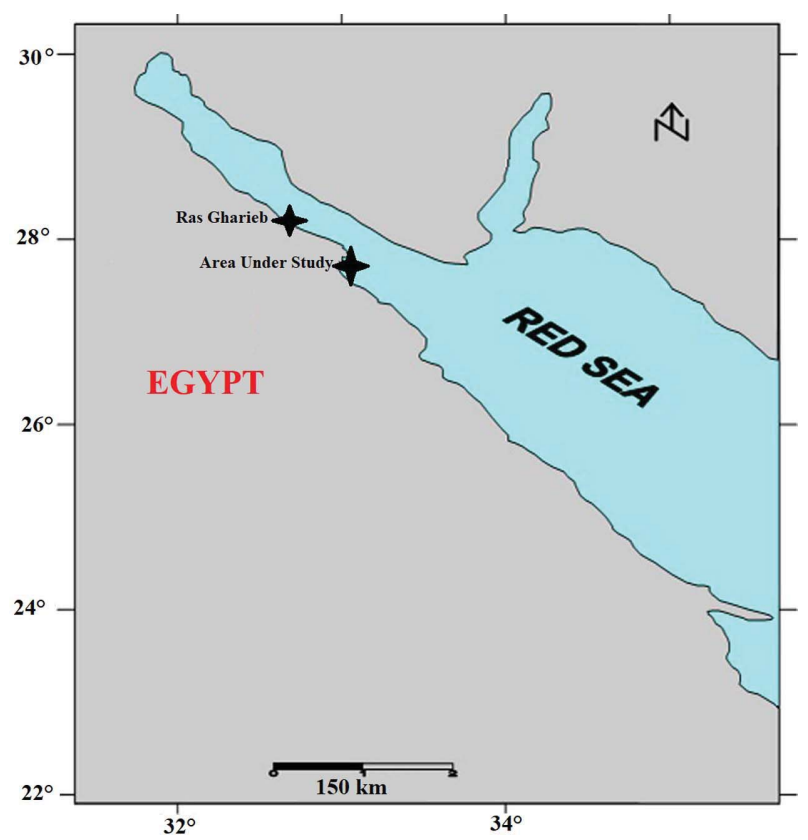

Fig. 1. Map of the Ras Gharib area and the location of sampling site.

[10]. From these solutions, serial dilutions were made, up to $10^{6}$, then each dilution was added to the starch nitrate medium in $0.1 \mathrm{ml}$ increments. with the following components $\left(\mathrm{gl}^{-1}\right)$ : 20 starch, $0.5 \mathrm{~K}_{2} \mathrm{HPO}_{4}, 1 \mathrm{KNO}_{3}$, $0.5 \mathrm{MgSO}_{4} 7 \mathrm{H}_{2} \mathrm{O}, 0.01 \mathrm{FeSO}_{4}, 15$ agar [11] at $\mathrm{pH}$ 7.0. It was fortified with griseofulvin and $0.05 \mathrm{ppm}$ chloramphenicol. After that, the culture 7 days at $28 \pm 2{ }^{\circ} \mathrm{C}$ was incubated in incubator (BDS-T 100/NS Biotec, Egypt). Preliminary selection of actinomycete colonies was made based on a morphology of colony, and they were streaked on the previous medium. For further identification tests, in the refrigerator at $2^{\circ} \mathrm{C}$ isolates were held.

\section{Screening of biosurfactant producers}

The selected isolates have been inoculated into a $500 \mathrm{ml}$ flask of Erlenmeyer with $100 \mathrm{ml}$ Kim biosurfactant medium. It consisting of $\left(\mathrm{gl}^{-1}\right)$ : $\mathrm{NaNO}_{3}, 1.0$; $\mathrm{KH}_{2} \mathrm{PO}_{4}, 0.1 ; \mathrm{MgSO}_{4} 7 \mathrm{H}_{2} \mathrm{O}, 0.1 ; \mathrm{CaCl}_{2}, 0.1$; yeast extract, $0.2 \%$ and $3 \%$ olive oil as the carbon source at $\mathrm{pH}$ 6.0 [12]. For 5 days, the cultures of broth were incubated at $32^{\circ} \mathrm{C}$ in a shaker incubator (Benchmark Scientific Incu-Shaker 10L, USA) at $120 \mathrm{rpm}$ min. Positive results were considered actinomycete cultures that emulsified oil as evidence of biosurfactant producing activity. Further tests were carried out to validate biosurfactant 
output by the screened strains. The existence of biosurfactant in cell-free supernatant was investigated using drop collapsing tests, hemolytic tests, emulsifying capacity, and surface tension measurements.

\section{Drop collapsing test}

After $1 \mathrm{~min}$ of adding five $\mathrm{ml}$ of supernatant of culture to two $\mathrm{ml}$ of mineral oil surface, the drop shape was examined. Cultures that produced positive $(+)$ biosurfactant produced flat drops, but cultures that produced round drops produced negative (-) results [13].

\section{Hemolytic test}

Actinomycetes isolates are grown in Blood Agar. $1.5 \mathrm{ml}$ sterile blood was pipetted into an Erlenmeyer flask containing $100 \mathrm{ml}$ mineral agar medium $(1.8 \mathrm{~g}$ $\mathrm{K}_{2} \mathrm{HPO}_{4}, 4.0 \mathrm{~g} \mathrm{NH}_{4} \mathrm{CI}, 0.2 \mathrm{~g} \mathrm{MgSO}_{4} \cdot 7 \mathrm{H}_{2} \mathrm{O}, 0.1 \mathrm{~g} \mathrm{NaCl}$, $0.01 \mathrm{~g} \mathrm{FeSO}_{4} \cdot 7 \mathrm{H}_{2} \mathrm{O}$ in $1 \mathrm{~L}$ and $15 \mathrm{~g}$ agar). Until it became frozen and solid, the sterile blood medium was poured. The potential biosurfactant isolates were inoculated on blood medium, which was incubated at $32^{\circ} \mathrm{C}$ for 7 days. The hemolysis zone and changed of color produced by the behavior actinomycetes were tested [14].

\section{Production of lipase}

Using tributyrin agar plates (5.0 g Special peptone; $3.0 \mathrm{~g}$ Yeast extract and agar $12 \mathrm{~g}$ in $1 \mathrm{~L}$ ), the lipase formed by pure marine actinomycetes cultures was determined. After being inoculated, the plates were incubated at $30^{\circ} \mathrm{C}$ for 7 days. After the incubation period, A clear zone around the colonies was tested on the plates [15].

\section{Emulsifying capacity}

Emulsification index (E24) supernatant after adding volume of paraffin oil ( $\mathrm{v}: \mathrm{v})$ was determined, then vortexed at highest speeds two min, to the sample cultures and allowed to stand for $24 \mathrm{~h}$. The E24 percentage with the following equation was determined [16].

$$
\begin{aligned}
\text { E24 }= & (\text { emulsion formed }) \text { Height }(\mathrm{cm}) \times 100) / \\
& \text { Total height of solution }(\mathrm{cm}) .
\end{aligned}
$$

\section{Surface tension measurement}

Measurements of surface tension $\mathrm{mN} / \mathrm{m}$ (mille Neuton/ meter) have been determined using centrifugation of cell-free actinomycetes culture by using surface tensiometer (TD 1 Lauda tensiometer, Germany) [17].

\section{Actinomycetes isolate identification}

Morphological, physiological, biochemical, and molecular approaches were used to identify the most potent marine actinobacterial isolates [18]. DNA was isolated and purified from the selected actinomycetes. $16 \mathrm{~S}$ sequence analysis was used to characterize the genotype, Finally, Bioedit was used to perform several alignments of the sequences of the members that are the most closely related [11].

\section{Medium optimization for highest production of biosur- factant}

By using series experiments, the medium was optimized by changing one variable at a time while maintaining the other variables constant at a set of conditions. To increase biosurfactant productivity, two factors were chosen: the source of carbon and the source of nitrogen. The sources of carbon which used is dextrose, sucrose, mannitol, xylose, maltose, glycerol, and glucose (20 g/l). Separate filtration using bacteriological filters was used to sterilize the carbon sources, and then applied under aseptic conditions to the production medium. In order to determine the best nitrogen sources in biosurfactant production at concentrations of $10 \mathrm{~g} / \mathrm{l}$ with the optimal carbon source, yeast extract, urea, peptone, tryptone, ammonium sulfate, and beef extract were used [19].

\section{Stability of biosurfactants activities}

The stability of biosurfactants was studied in cultures grown on Kim biosurfactant medium at various temperatures $\left(20-60^{\circ} \mathrm{C}\right)$ and $\mathrm{pH}(4-11)$. To the same growing medium, various $\mathrm{NaCl}$ concentrations were used to measure the salinity influencing emulsification activity (0$30 \%$ ). Both checked and medium were incubated for 7 days at $120 \mathrm{rpm}$ under shaking conditions. The activity of emulsification has been determined [20].

\section{Biosurfactant extraction}

A solvent extraction method [21] was used to extract the biosurfactants provided by $S$. althioticus RG3 and Str. californicus RG8 from the filtrate. The biosurfactant was extracted and purified using $4 \mathrm{~L}$ of culture broth 
centrifuged for the first time at $7000 \mathrm{rpm}$ and $4{ }^{\circ} \mathrm{C}$ for $25 \mathrm{~min}$. The crude material was extracted by combining it with a similar equal quantity of chloroform: methanol at a $2: 1(\mathrm{v} / \mathrm{v})$ ratio in a separator flask, shaking it vigorously, and letting it sit for $30 \mathrm{~min}$. The bottom aqueous layer of the separation funnel was withdrawn, white bioemulsifier layer immediately above it was collected in petri dishes and evaporated in a $40-45^{\circ} \mathrm{C}$ oven [10].

\section{The biosurfactant's chemical composition}

Lowry's method was used to assess concentration of protein from isolated biosurfactant [22], using bovine serum albumin as standard. By using the method of phenol sulfuric acid, carbohydrate content was determined [23].

\section{Fourier Transform Infrared Spectroscopy (FTIR)}

In City of Scientific Research and Technological, Alexandria, Egypt, the functional classes of isolated biosurfactants from S. althioticus RG3 and Str. californicus RG8 were identified using (FTIR) using a spectrum 400 instrument (PerkinElmer, USA). Under ambient conditions, 400-4000 $\mathrm{cm}^{-1}$ were the spectral resolution and the precision of the wave number.

\section{Antimicrobial assay}

The antimicrobial activity of the biosurfactants production against Vibrio alginolyticus MK170250, Escherichia coli ATCC 8739, Pseudomonas aeruginosa ATCC 4027, and Staphylococcus aureus ATTC 25923 was determined using agar well diffusion method. In a nutshell, $100 \mu \mathrm{l}$ of aqueous biosurfactant solutions is poured into 6-mm-diameter wells in the pour plated nutrient agar. The plates were incubated at $37^{\circ} \mathrm{C}$ for $24 \mathrm{~h}$. The presence of a clear zone around the wells indicated antimicrobial activity [24]. These bacterial pathogens were kindly provided by the staff members of the National Institute of Oceanography and Fisheries (NIOF), Egypt.

\section{Antifouling activity}

In a conical flask $(50 \mathrm{ml})$ containing sterilized cover glass, seawater $(1 \mathrm{ml})$ was mixed with sterile sweater (20 ml) and incubated overnight at $28^{\circ} \mathrm{C}$. About $500 \mathrm{ul}$ of aqueous solutions of the biosurfactant extract was added into the flask (as an antifouling agent). The flask was filled with $500 \mu \mathrm{l}$ of biosurfactant aqueous solutions (as an antifouling agent). The cover glass was washed in water, dried at room temperature, and examined under the microscope after ten minutes of dying with crystal violet solution $(0.4 \%)$ [11].

\section{Data analysis}

All experiments were carried out in triplicate. The values are the mean \pm standard deviation (SD) of three separate experiments. The least significant difference $\left(\mathrm{LSD}_{5 \%}\right)$ was used in a one-way analysis of variance.

\section{Results and Discussion}

\section{Isolation and production of biosurfactants}

Nine actinomycetes isolates were isolated from sediment that has been tainted with fuel oil in the Ras Garib region of Egypt's Gulf of Suez and screened for biosurfactant production. Extracellular biosurfactant production of 3\% olive oil from Kim's medium was initially screened for all these isolates as the only source of carbon. Out of nine isolates, only two isolates, RG3 and RG8, showed positive results. During the screening process, olive oil was used as the carbon source for biosurfactant production was increased using actinomycetes [25]. One of the parameters for selecting potential producer biosurfactants is the emulsification activity. Biosurfactant productivity is calculated by emulsifying activities [26]. The marine actinomycetes isolates RG3 and RG8 had the highest emulsification indices, as shown in (Table 1),

Table 1. Characterization of biosurfactant activities.

\begin{tabular}{cccccc}
\hline Isolate & $\begin{array}{c}\text { Emulsifica- } \\
\text { tion index } \\
(\%)\end{array}$ & Hemolaysis & $\begin{array}{c}\text { Drop } \\
\text { collapse }\end{array}$ & $\begin{array}{c}\text { Lipase } \\
\text { production }\end{array}$ & $\begin{array}{c}\text { Surface } \\
\text { tension } \\
\mathrm{mN} / \mathrm{m}\end{array}$ \\
\hline RG1 & $30 \pm 1.7$ & - & - & + & - \\
RG2 & - & - & - & - & - \\
RG3 & $60 \pm 2.5$ & + & + & + & $77.2 \pm 2.4$ \\
RG4 & - & - & - & - & - \\
RG5 & $25 \pm 1.5$ & - & - & + & - \\
RG6 & - & - & - & + & - \\
RG7 & - & - & - & - & - \\
RG8 & $53 \pm 2.2$ & + & + & + & $69.2 \pm 2.4$ \\
RG9 & - & - & - & - & - \\
\hline
\end{tabular}

Results are expressed as mean $\pm \mathrm{SD}(n=3)$ where mean is significant at $p<0.05$. (+) positive result, (-) Negative result. 


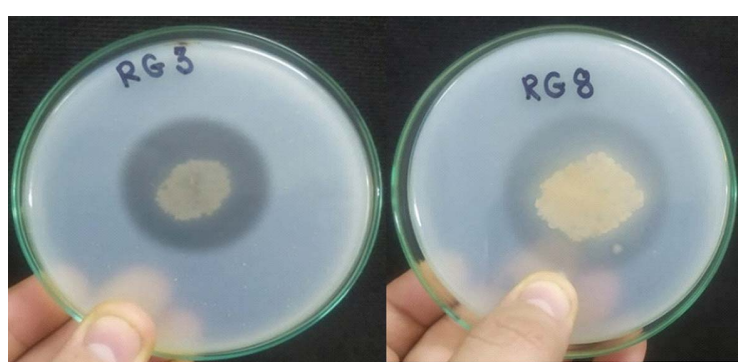

Fig. 2. Screening of actinomycetes isolates (RG3 and RG8) for biosurfactant production: lipase activity test showing a clear zone.

of $60 \pm 2.5 \%$ and $53 \pm 2.2 \%$, respectively. Korayem [15] and his team found that, Streptomyces isolate $5 \mathrm{~S}$ had an emulsification index of $31.74 \%$. After initial screening by Zambry and his team [25], the emulsification index test (E24) has provided positive results for all isolates of actinomycete, the results varying between $84.11 \%$ to $95.80 \%$. Selected isolates showing positive results against the collapse of the drop and hemolytic action. In this analysis, the biosurfactant producer was screened with lipase activity. Kokare says that [27], lipase in the water/oil surfaces was responsible for the operation, and therefore actinomycetes have shown that lipase is capable of producing bioemulsifiers. In this work, isolates RG3 and RG8 showed zones of lysis around the colonies (Fig. 2). The surface tension of the supernatant and purified biosurfactant was measured using a surface tensiometer. Both marine actinomycetes isolates (RG3 and RG8) reduced surface tension to values of $77.24 \pm$ $2.4 \mathrm{mN} / \mathrm{m}$ and $69.27 \pm 2.4$ respectively, recording positive results for biosurfactant activity. Fig. 3 shows the

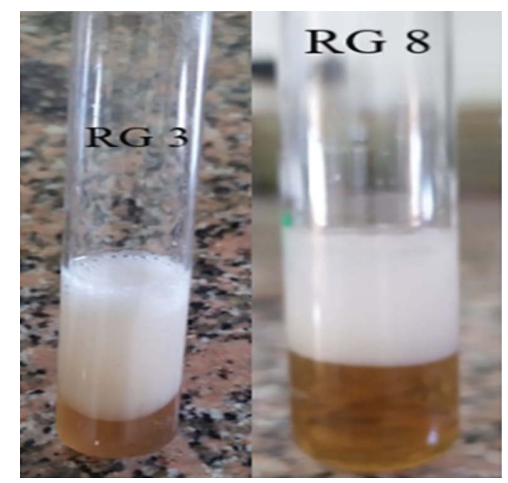

Fig. 3. Emulsion formation using paraffin oil and extraction of isolates (RG3 and RG8). measurements of the surface tension effects and those caused by a decrease in the surface tension value. Arifiyanto et al. [14] reported that three actinomycetes isolates belong to Streptomyces sp. named AF6, AB8, and AA1, which were 56.22, 57.27 and $57.33 \mathrm{mN} / \mathrm{m}$ surface tension values, respectively. If a bacterial isolate surface tension decreased to $40 \mathrm{mN} / \mathrm{m}$ or less, Cooper and Goldenberg [28] suggest that it could be a promising producer of biosurfactants. The marine organism Virgibacillus salaries displayed a decrease in tension on the surface $(30 \mathrm{mN} / \mathrm{m})$, an E24 $=80 \%$, and three morphologically distinct colonies, collapse of drop , distribution of oil , and hemolysis of blood all showed promising effects [29].

\section{Biochemical and molecular characterization}

Table 2 displays the morphological, physiological, and

Table 2. Biochemical identification of biosurfactant producing marine actinomycetes isolates.

\begin{tabular}{|c|c|c|}
\hline \multirow[b]{2}{*}{ Characters } & \multicolumn{2}{|c|}{ Actinomycetes isolates } \\
\hline & $\begin{array}{l}\text { Streptomyces } \\
\text { althioticus RG3 }\end{array}$ & $\begin{array}{c}\text { Streptomyces } \\
\text { californicus RG8 }\end{array}$ \\
\hline \multicolumn{3}{|c|}{ Morphological characters } \\
\hline Substrate mycelium & Pale brown & Cream \\
\hline Aerial mycelium & Cream & White \\
\hline Diffusible pigments & Beige & - \\
\hline \multicolumn{3}{|l|}{ Utilization of } \\
\hline Lipase & + & + \\
\hline Starch & + & + \\
\hline Lactose & + & + \\
\hline Dextrose & + & + \\
\hline Maltose & + & + \\
\hline Cellulose & + & + \\
\hline Mannitol & + & - \\
\hline Sucrose & + & + \\
\hline Glucose & + & - \\
\hline \multicolumn{3}{|l|}{ Biochemical test } \\
\hline Citrate utilization & + & - \\
\hline $\mathrm{H}_{2} \mathrm{~S}$ production & - & - \\
\hline Urase hydrolysis & + & + \\
\hline Indole production & - & - \\
\hline Vogas Proskauer & - & - \\
\hline Gelatin hydrolysis & + & + \\
\hline
\end{tabular}

(+) positive result, (-) Negative result. 
Table 3. Accession numbers and percentages of similarity to the nearest known species.

\begin{tabular}{clcc}
\hline Isolate No. & Identification & Strain No \& (Accession No.) of closely related species & Similarity (\%) \\
\hline RG3 & Streptomyces althioticus & CSSP544 \& NR_115392 & 95 \\
RG8 & Streptomyces californicus & CSSP711 \& NR_115432 & 95 \\
\hline
\end{tabular}
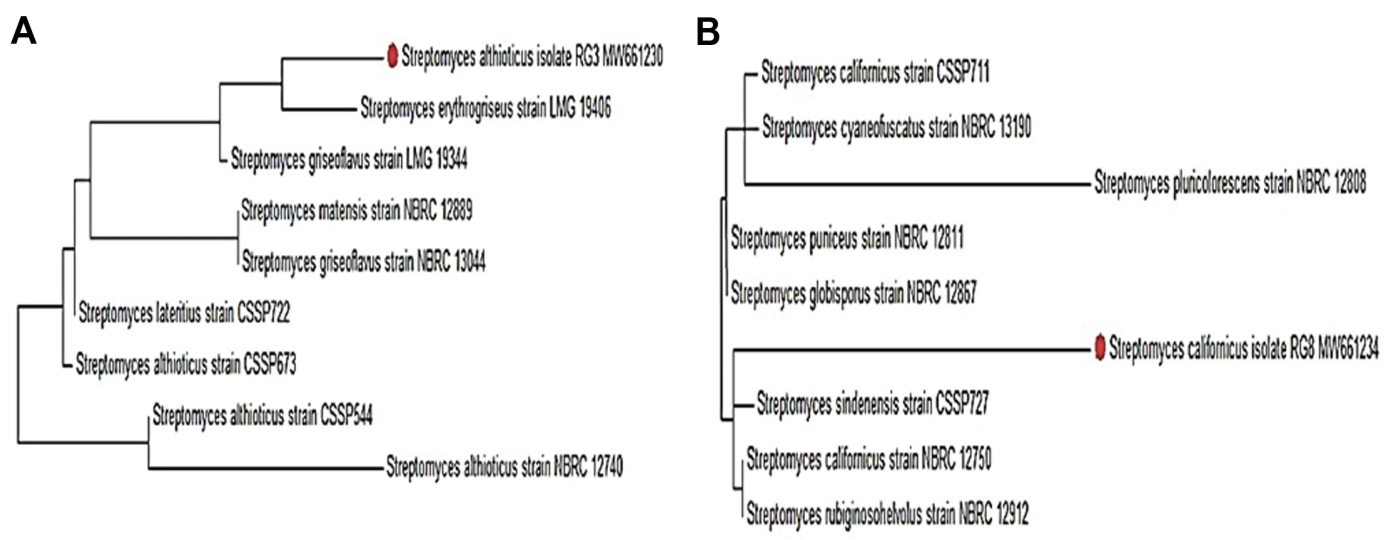

Fig. 4. Phytogenic tree of isolate RG3 (A) and RG8 (B) based 16S rRNA based dendrogram showing the phytogenic position of isolates RG3 and RG8 among representatives of related bacterial species. The tree was constructed using Bioedit method Gene Sequence Analysis.

biochemical characteristics of the selected isolates. The sequences of $16 \mathrm{~S}$ rRNA for the selected RG3 and RG8 isolates were compared with the Streptomyces sp. sequence using multiple sequence alignment to validate the actinomycete isolate's identification. Using agarose gel electrophoresis, an experimental study of PCR amplification was performed. Table 3 shows the GenBank accession numbers of the closest neighbors of isolates RG3 and RG8. Isolate RG3 was assigned as $S$. althioticus RG3 with the accession number (MW661230) Fig. 4A. Isolate RG8 was given the name Str. californicus RG8 with accession number (MW661234) as it is affiliated according to the genus Str. californicus Fig. 4B.

\section{Factors affecting of fermentation condition}

There has been considerable research into the generation of biosurfactants by actinomycetes under extreme conditions for commercial use [30]. The effect of conditions, including carbon sources, nitrogen sources, higher salt, temperature, and $\mathrm{pH}$, on the production of biosurfactant from the marine isolates of S. althioticus RG3 and Str. californicus RG8, to assess its stability.

\section{Effect of various sources of carbon}

The amount of biosurfactant generated was measured and found to be relying on the composition of medium. Changes in the carbon source in culture media was caused by biosurfactant secretion in shaken-flask experiments. The statistical analysis revealed that the difference in biosurfactant activity at different carbon sources was statistically significant for selected isolates RG3 and RG8 (LSD $0.05=0.18$ and $0.05=0.22$ ). Sucrose, dextrose, and glucose were found to be the most effective sources of carbon for production biosurfactant. Glucose (2\% w/v) in the two strains S. althioticus RG3 and Str. californicus RG8 were the carbon sources producing the most biosurfactants (Fig. 5). Nutrient substrates were screened, and it was founded that these isolates supported growth in all substrates, although xylose was limited in yield. Khopade and his team [19] said that, production of biosurfactant though marine Streptomyces sp. isolate B3 was decreased surface tension to 29 $\mathrm{mN} / \mathrm{m}$ and the emulsifying activity showed $80 \%$. Streptomyces sp. generated the most biosurfactants when sucrose was used as the carbon source, according to previous research $[15,19]$.

\section{Effectiveness of nitrogen sources}

Production of biosurfactant is affected by the nitrogen source, as shown in Fig. 5. Macro-nutrients need specific 

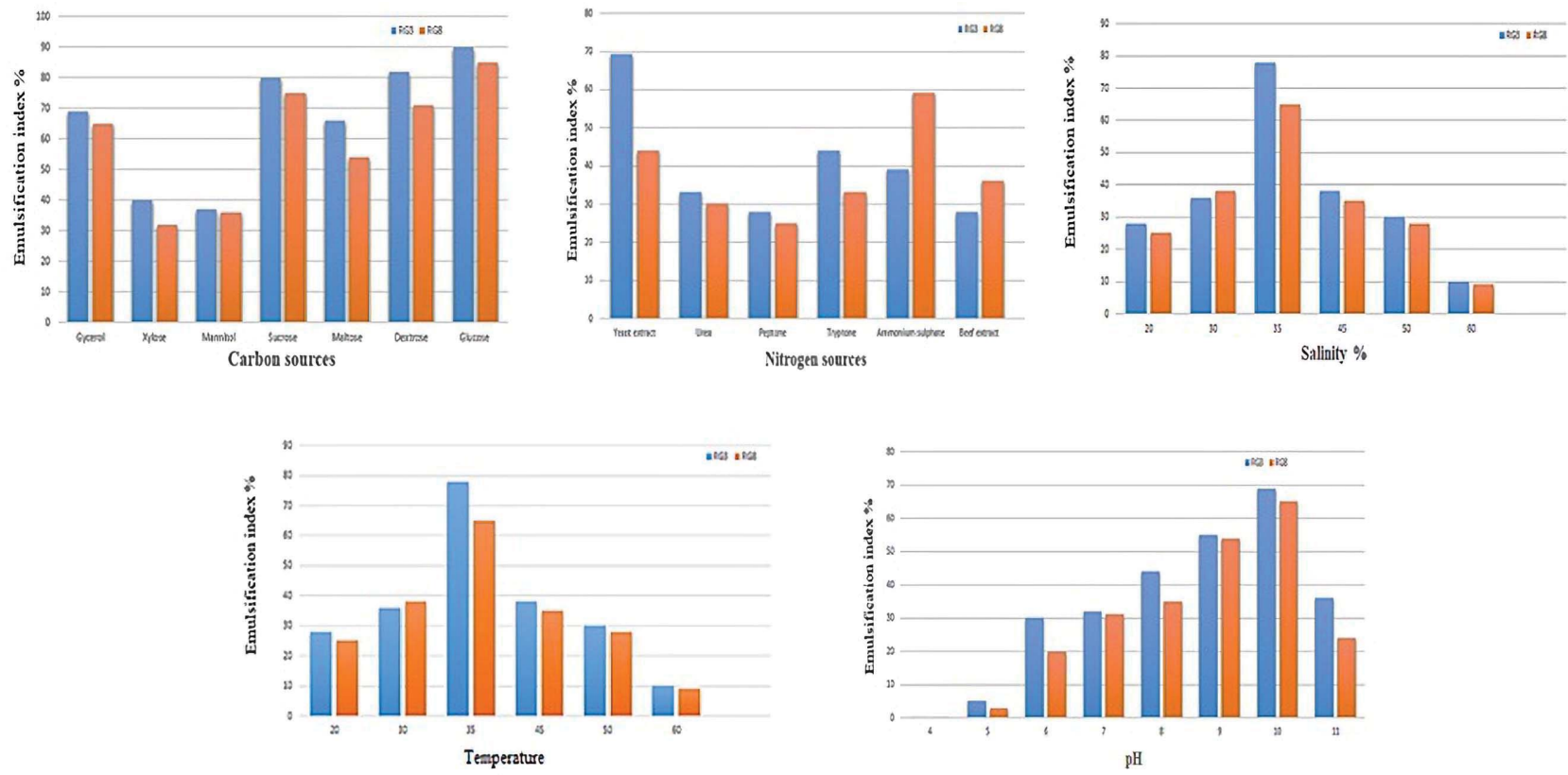

Fig. 5. Effect of culture conditions on emulsifying activity of broth media in biosurfactant relation production by Streptomyces althioticus RG3 and Streptomyces californicus RG8: carbon source, nitrogen source, $\mathrm{NaCl}$ concentration, temperature and pH. Three replicates of the tests were used; The data are shown in the form of a mean value with error bars representing the standard deviation (SD). Statically significant differences between the samples (LSD 5\%) are estimated: $(0.18$ and 0.22$),(0.18$ and 0.14$),(0.11$ and 0.8$),(1.3$ and 1.2$)$ and (0.24 and 0.21$)$ respectively.

conditions to produce high concentrations of biosurfactants [19]. In Significant variations between the different types of nitrogen sources (LSD $0.05=0.18$ ) in isolate S. althioticus RG3 and it has been found that the nitrogen is required for growth and production of biosurfactant was yeast extract, which had an E24 of 69.25\%, while ammonium sulfate was best for the isolation of Str. californicus RG8, with an E24 of 59.21\% and showed significant variation (LSD $0.05=0.14$ ). Other studies in which organic nitrogen sources were favored over inorganic sources produced similar findings [31, 32].

\section{Stability of bio-surfactant activities}

Effectiveness of different salt concentrations. Fig. 5 indicates that the emulsification of S. althioticus RG3 was stable $(70 \%)$ with $10 \% \mathrm{NaCl}$, and then gradually decreased to $15-30 \% \mathrm{NaCl}$ with a significant variation LSD $0.05=0.11$. Str. californicus RG8 emulsification operation was steadily increased from $10 \%$ to $15 \% \mathrm{NaCl}$ to $60 \%$, and then decreased to $20-30 \%$ with a significant variation LSD $0.05=0.8$. Khopade [19] reported that, in
$4 \%(\mathrm{w} / \mathrm{v}) \mathrm{NaCl}$, Streptomyces sp. B3 which isolated from marine resource generated the most biosurfactant (E24 $=78 \%$ ), and represented activity of emulsification (E24 = $60 \%)$ in the using of $9 \%(\mathrm{w} / \mathrm{v}) \mathrm{NaCl}$. Elkhawaga [10] showed, Streptomyces griseoplanus (MS1) has ability to produce biosurfactant stable at concentrations of the $\mathrm{NaCl}$ up to $10 \%$. Elazzazya [29] stated that, in $4 \%(\mathrm{w} / \mathrm{v})$ $\mathrm{NaCl}$, biosurfactant synthesis was obtained.

Various temperatures effectiveness. One of the most critical parameters in the bioprocess was temperature. The statistical analysis indicated that the difference in activity of biosurfactant at different incubation temperatures was statistically significant $($ LSD $0.05=0.137$ ) for isolate RG3 and (LSD $0.05=0.122$ ) for isolate RG8. At $35^{\circ} \mathrm{C}$, the highest emulsifying activity of S. althioticus RG3 and Str. californicus RG8 was observed, at emulsifying indices of $78 \%$ and $65 \%$, respectively. Even so, there was still stable biosurfactant output from $45^{\circ} \mathrm{C}$ to $50^{\circ} \mathrm{C}$, implying that both isolates were thermotolerant (Fig. 5), and indicating that the biosurfactant is moderately thermostable. The composition of the biosurfactant 
in Arthrobacter paraffineus and Pseudomonas sp. changed as the temperature changed [13, 33]. A similar study indicated that the biosurfactant activity was the highest when the marine Streptomyces sp. B3 was cultivated at $30^{\circ} \mathrm{C}(\mathrm{E} 24=80 \%)[19]$. At $30-40^{\circ} \mathrm{C}$, The surface tension of Pseudomonas sp. (MW2) culture broth was decreased, according to Dahil [34]. Deng and his team [35] showed that rising level of biosurfactant was generated by Achromobacter sp. HZ01 at $40-80^{\circ} \mathrm{C}$.

\section{Effect of pH}

Due to the large amount of using biosurfactants in the production of detergents, it was necessary to choose an alkaline biosurfactant from isolated bacteria [20]. As seen in (Fig. 5), the highest level of emulsification operation for S. althioticus RG3 and Str. californicus RG8 was the alkaline (pH 10) and reached 69\% and 65\%, respectively. This result indicated a significant variation between the results (LSD $0.05=0.24$ and 0.21) However, no significant difference was observed in the $\mathrm{pH}$ range 4-9. This may be attributed to greater surfactant micelle stability with fatty acids in the precent of $\mathrm{NaOH}$ and secondary metabolites precipitation with rising values of $\mathrm{pH}$ [19]. Operation for the emulsification was decreased due to a decrease in the value of $\mathrm{pH}$ moving from the basal to the acidic zone (9 to $5 \mathrm{pH}$ ), because of partial biosurfactant precipitation [36]. In alkaline $\mathrm{pH}$ (8-9), the bio-emulsifier activity was higher than in acidic $\mathrm{pH}$. (5) [10]. Nadem et al., stated that Streptomyces sp. SS 20 , isolated, soil contaminated with hydrocarbons has a high activity of bioemulsifying and stability over a wide temperature spectrum $\left(30-100^{\circ} \mathrm{C}\right)$ and $\mathrm{pH}$ level of 3-7 [37]. According to El-Sersy, the E24 of B. subtilis was stable in a $\mathrm{pH}$ range of 6 to 10 [38]. The $\mathrm{pH}$ effect for biosurfactants of various microorganisms on surface activity has been recorded [39].

Chemical composition of the biosurfactants. $S$. althioticus RG3 produces a biosurfactants had a chemical structure of $30 \%$ protein, $20 \%$ carbohydrate, and $50 \%$ lipids. Str. californicus RG8 provided a biosurfactant with a chemical composition of $18 \%$ proteins, $45 \%$ carbohydrates, and $37 \%$ lipids. Lipids, glycolipids, lipopeptides, and polysaccharide protein complexes are examples of biosurfactants isolated from microorganisms [40]. Biosurfactant biochemical composition is likely to be influenced by the substrates used in the growth medium. In the founded of refinery soybean oil, The biosurfactant production from C. lipolytica UCP0988 contained proteins in the rate of $50.0 \%$, carbohydrates in the rate of $8.0 \%$, and lipids in the rate of $20.0 \%$, according to Rufino and his colleagues [41]. Thavasi recorded other findings, such as the biosurfactant production from $L$. delbrueckii containing carbohydrates in the rate of $30.0 \%$ and lipids in the rate of $70.0 \%$ [42]. The biosurfactant of C. Sphaerica UCP0995 contained 15.0\% carbohydrate and $70.0 \%$ lipids, according to Luna and his team [43].

Fourier Transform Infrared Spectroscopy (FTIR). The biosurfactant developed by S. althioticus RG3 was analyzed using FTIR and showed the presence of 11 clear absorption peaks at $3343.1,1653.7,1401.8,1084.9,1007.2$, $988.2,832.6,702.8,663.4,618.2,543.8 \mathrm{~cm}^{-1}$, as shown in

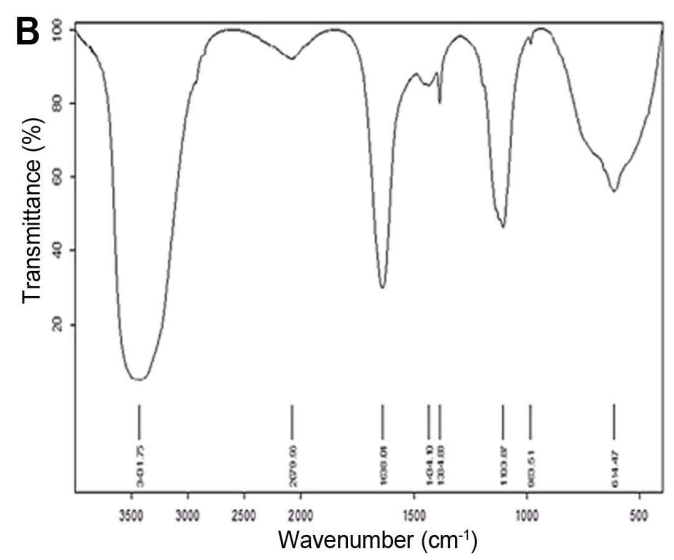

Fig. 6. FTIR analysis of biosurfactant production by Streptomyces althioticus RG3 (A) and Streptomyces californicus RG8 (B). 
Table 4. Antimicrobial activities of the biosurfactants production by Streptomyces althioticus RG3 and Streptomyces californicus RG8.

\begin{tabular}{lcc}
\hline \multicolumn{1}{c}{ Microorganism } & \multicolumn{2}{c}{ Antimicrobial assays } \\
\cline { 2 - 3 } & Streptomyces althioticus RG3 & Streptomyces californicus RG8 \\
\hline Vibrio alginolyticus MK170250 & +++ & + \\
Escherichia coli ATCC 8739 & ++ & + \\
Pseudomonas aeruginosa ATCC 4027 & + & - \\
Staphylococcus aureus ATTC 25923 & + & + \\
\hline
\end{tabular}

" + " sign demonstrates microbial growth inhibition, whereas "-" The failure to prevent the growth of the microorganisms under investigation. $(+++)$ strongest effect, $(++)$ moderate effect.
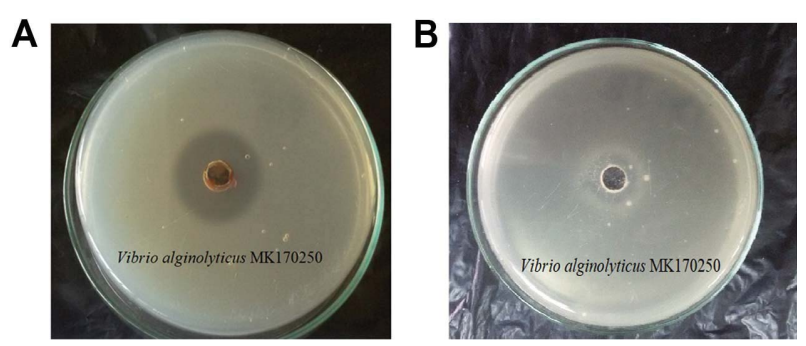

Fig. 7. Antagonistic effects of biosurfactants production by Streptomyces althioticus RG3 (A) and Streptomyces californicus RG8 (B) against Vibrio alginolyticus MK170250.

(Fig. 6A). FTIR analysis of produced biosurfactant by $S$. californicus RG8 depicts the presence of eight clear absorption peaks at 3431.7, 2079.9, 1638, 1434.1, 1384.8, 1103.8, 983.5, $614.48 \mathrm{~cm}^{-1}$, as shown in (Fig. 6B). Peaks at 3343.1 and $3431.7 \mathrm{~cm}^{-1}$ were amide groups, and a diketone group were apparent in 1653.7 and $1638.01 \mathrm{~cm}^{-1}$. The peaks at 2079.9 and $1084.9 \mathrm{~cm}^{-1}$ were attributed to $\mathrm{C}-\mathrm{O}$ bonds. The absorption peak at 1401.8 and $1434.1 \mathrm{~cm}^{-1}$ indicates for nitrosamine presence. In $1384.8 \mathrm{~cm}^{-1}$ peaks was isopropyl, whereas that at $1103.8 \mathrm{~cm}^{-1}$ refer to ester carbonyl group indicates. In $1007.2-983.5 \mathrm{~cm}^{-1}$ peaks were polysaccharides. The peak at $832.63 \mathrm{~cm}^{-1}$ was an aromatic group with absorption peaks at $702.8-543.8 \mathrm{~cm}^{-1}$. These findings agree with the results of other studies $[10,44]$.

\section{Antimicrobial activity}

Because of their anti-adhesive agents and enzyme inhibitors, biosurfactants have operated as fungicidal, bactericidal, insecticidal, and antiviral ingredients [14, $19,45]$. In this study, we observed that an increase in the biosurfactants concentration led to improvement of its antimicrobial effects (Table 4). The highest antimicrobial effects of biosurfactants were observed against Vibrio alginolyticus MK170250 from S. althioticus RG3 (Fig. 7) followed by the effects against $E$. coli ATCC 8739. Gram negative bacteria are more antagonistic to Streptomyces VITSDK1 spp. surfactants, with an inhibition zone of $10.3 \mathrm{~mm}$ in Klebsiella pneumoniae. Staphylococcus aureus is inhibited by Streptomyces VITSDK1 spp. surfactants by $5.3 \mathrm{~mm}$ [46]. Streptomyces sp. strain AF1 has a distinct personality. It
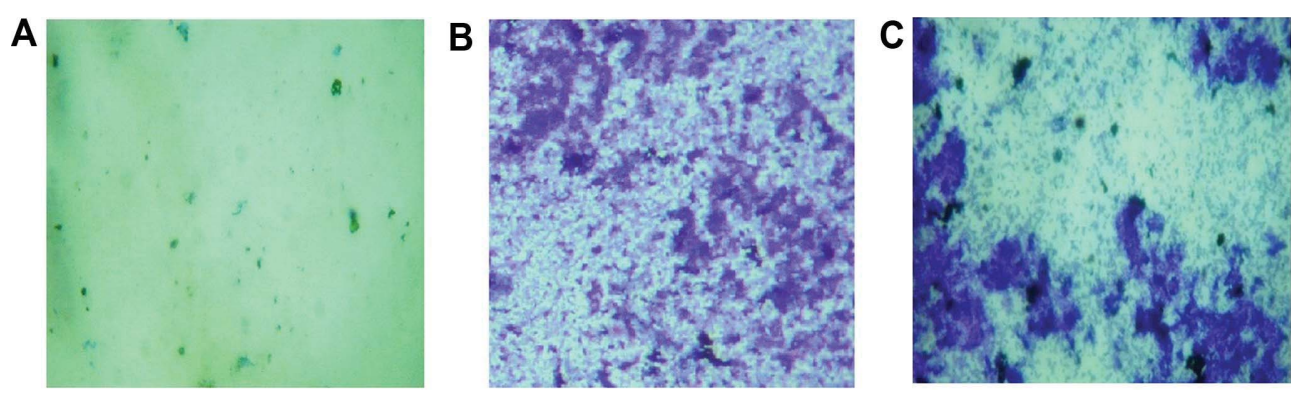

Fig. 8. Photographs illustrating the antifouling effect of the biosurfactants from Streptomyces althioticus (RG3) on the biofilm formation, the emergence of a small number of bacterial colonies (A), Streptomyces californicus RG8 a large (B) number of bacterial colonies and the effect without the biosurfactant compounds (Control), the emergence of large numbers of bacterial colonies (C). 
can grow at a high temperature of about $70^{\circ} \mathrm{C}$ and generate an antimicrobial biosurfactant [14].

\section{Antifouling activity}

Fig. 8 illustrated the inhibitory action of S. althioticus (RG3) biosurfactants on bacterial biofilm formation. The biosurfactants production by $S$. althioticus RG3 reduced the density of bacterial cells and acted as an anti-biofouling agent, while Str. californicus RG8 not achieved that. Napyradiomycin which production from marine Streptomyces aculeolatus isolate PTM-029 exhibited the higher antibacterial activity, the higher microfouling inhibitory activity, and the most potent antimicrofouling activity [47]. Two marine actinobacterial strains, S. althioticus RG3 and Str. californicus RG8, isolated from Ras Garib, Gulf of Suez, Egypt was able to produce very stable biosurfactants under stress conditions, additionally that can be valuable in several industries like pharmaceutical industries and antifouling manufacturing.

\section{Conflict of Interest}

The authors have no financial conflicts of interest to declare.

\section{References}

1. Naughton P, Marchant R, Naughton V, Banat I. 2019. Microbial biosurfactants: current trends and applications in agricultural and biomedical industries. J. Appl. Microbiol. 127: 12-28.

2. Marchant R, Banat IM. 2012. Biosurfactants: a sustainable replacement for chemical surfactants? Biotechnol. Lett. 34: 15971605.

3. Twigg MS, Baccile N, Banat IM, Déziel E, Marchant R, Roelants S, et al. 2020. Microbial biosurfactant research: time to improve the rigour in the reporting of synthesis, functional characterization and process development. Microb. Biotechnol. 14: 147-170.

4. Banat IM, Franzetti A, Gandolfi I, Bestetti G, Martinotti MG, Fracchia L, et al. 2010. Microbial biosurfactants production, applications and future potential. Appl. Microbiol. Biotechnol. 87: 427-444.

5. Sengupta S, Pramanik A, Ghosh A, Bhattacharyya M. 2015. Antimicrobial activities of actinomycetes isolated from unexplored regions of Sundarbans mangrove ecosystem. BMC Microbiol. 15: 1-16.

6. Shivlata L, Tulasi S. 2015. Thermophilic and alkaliphilic actinobacteria: biology and potential applications. Front. Microbiol. 6: 1014.

7. Ballav S, Kerkar S, Thomas S, Augustine N. 2015. Halophilic and halotolerant actinomycetes from a marine saltern of Goa, India producing anti-bacterial metabolites. J. Biosci. Bioeng. 119: 323330.

8. Poomthongdee N, Duangmal K, Pathom-aree W. 2015. Acidophilic actinomycetes from rhizosphere soil: diversity and properties beneficial to plants. J. Antibiot. 68: 106-114.

9. Nurkanto A, Listyaningsih F, Julistiono H, Agusta A. 2017. Eksplorasi keanekaragaman Aktinomisetes Tanah Ternate sebagai sumber antibiotik. J. Biol. Indones. 6: 325-340.

10. Elkhawaga M. 2018. Optimization and characterization of biosurfactant from Streptomyces griseoplanus NRRL-ISP 5009 (MS 1). J. Appl. Microbiol. 124: 691-707.

11. Abd-Elnaby HM, Abo-Elala GM, Abdel-Raouf UM, Hamed MM. 2016. Antibacterial and anticancer activity of extracellular synthesized silver nanoparticles from marine Streptomyces rochei MHM13. Egypt. J. Aquat. Res. 42: 301-312.

12. Kim SH, Lim EJ, Lee SO, Lee JD, Lee TH. 2000. Purification and characterization of biosurfactants from Nocardia sp. L-417. Biotechnol. Appl. Biochem. 31: 249-253.

13. Youssef NH, Duncan KE, Nagle DP, Savage KN, Knapp RM, Mclnerney MJ. 2004. Comparison of methods to detect biosurfactant production by diverse microorganisms. J. Microbiol. Methods 56: 339-347.

14. Arifiyanto A, Surtiningsih T, Agustina D, Alami NH. 2020. Antimicrobial activity of biosurfactants produced by actinomycetes isolated from rhizosphere of Sidoarjo mud region. Biocatal. Agric. Biotechnol. 24: 101513.

15. Korayem A, Abdelhafez A, Zaki M, Saleh E. 2015. Optimization of biosurfactant production by Streptomyces isolated from Egyptian arid soil using Plackett-Burman design. Ann. Agric. Sci. 60: 209217.

16. Techaoei S, Leelapornpisid P, Santiarwarn D, Lumyong S. 2007. Preliminary screening of biosurfactant-producing microorganisms isolated from hot spring and garages in Northern Thailand. Curr. Appl. Sci. Technol. 7: 38-43.

17. Bodour AA, Maier RM. 2003. Biosurfactants: types, screening methods, and applications. pp. 750-770. Wiley, New York.

18. Sharma M, Dangi P, Choudhary M. 2014. Actinomycetes: source, identification, and their applications. Int. J. Curr. Microbiol. App. Sci. 3: 801-832.

19. Khopade A, Ren B, Liu X-Y, Mahadik K, Zhang L, Kokare C. 2012. Production and characterization of biosurfactant from marine Streptomyces sp. B3. J. Colloid Interface Sci. 367: 311-318.

20. Barakat KM, Hassan SW, Darwesh OM. 2017. Biosurfactant production by haloalkaliphilic Bacillus strains isolated from Red Sea, Egypt. Egypt. J. Aquat. Res. 43: 205-211.

21. Maneerat S, Dikit P. 2007. Characterization of cell-associated bioemulsifier from Myroides sp. SM1, a marine bacterium. Cell 29: 770.

22. Lowry O, Rosebrough N, Farr A, Randall R. 1951. Protein measurement with the Folin phenol reagent. J. Biol. Chem. 193: 265-275..

23. Dubois M, Gilles K, Hamilton J, Rebers P, Smith F. 1956. Phenol sulphuric acid method for total carbohydrate. Anal. Chem. 26: 350. 
24. Madhu AN, Prapulla SG. 2014. Evaluation and functional characterization of a biosurfactant produced by Lactobacillus plantarum CFR 2194. Appl. Biochem. Biotechnol. 172: 1777-1789.

25. Zambry NS, Ayoib A, Noh NAM, Yahya ARM. 2017. Production and partial characterization of biosurfactant produced by Streptomyces sp. R1. Bioprocess Biosys. Eng. 40: 1007-1016.

26. Chakraborty S, Ghosh M, Chakraborti S, Jana S, Sen KK, Kokare C. 2015. Biosurfactant produced from Actinomycetes nocardiopsis A17: characterization and its biological evaluation. Int. J. Biol. Macromol. 79: 405-412.

27. Kokare C, Kadam S, Mahadik K, Chopade B. 2007. Studies on bioemulsifier production from marine Streptomyces sp. S1. Ind. J. Biotechnol. 6: 78-84.

28. Cooper DG, Goldenberg BG. 1987. Surface-active agents from two Bacillus species. Appl. Environ. Microbiol. 53: 224-229.

29. Elazzazy AM, Abdelmoneim T, Almaghrabi O. 2015. Isolation and characterization of biosurfactant production under extreme environmental conditions by alkali-halo-thermophilic bacteria from Saudi Arabia. Saudi J. Biol. Sci. 22: 466-475.

30. Demirjian DC, Morís-Varas F, Cassidy CS. 2001. Enzymes from extremophiles. Curr. Opin. Chem. Biol. 5: 144-151.

31. Kiran GS, Hema T, Gandhimathi R, Selvin J, Thomas TA, Ravji TR, et al. 2009. Optimization and production of a biosurfactant from the sponge-associated marine fungus Aspergillus ustus MSF3. Colloids Surf. B Biointerfaces 73: 250-256.

32. Kalyani A, Naga Sireesha G, Aditya A, Girija Sankar G, Prabhakar T. 2014. Production optimization of rhamnolipid biosurfactant by Streptomyces coelicoflavus (NBRC 15399T) using Plackett-Burman design. Eur. J. Biotechnol. Biosci. 1: 7-13.

33. Bento FM, Oliveira Camargo FA, Okeke BC, Frankenberger WT. 2005. Diversity of biosurfactant producing microorganisms isolated from soils contaminated with diesel oil. Microbiol. Res. 160: 249.

34. Dhail S. 2012. Isolation of potent biosurfactant producing bacteria from oil spilled marine water and marine sediments. Afr. J. Biotechnol. 11: 16751-16757.

35. Deng MC, Li J, Hong YH, Xu XM, Chen WX, Yuan JP, et al. 2016. Characterization of a novel biosurfactant produced by marine hydrocarbon-degrading bacterium Achromobacter sp. HZ 01. J. Appl. Microbiol. 120: 889-899.

36. Khopade A, Biao R, Liu X, Mahadik K, Zhang L, Kokare C. 2012. Production and stability studies of the biosurfactant isolated from marine Nocardiopsis sp. B4. Desalination 285: 198-204.

37. Hayder NH, Alaa S, Abdulmalik H. 2014. Optimized conditions for bioemulsifier production by local Streptomyces sp. SS 20 isolated from hydrocarbon contaminated soil. Rom. Biotechnol. Lett. 19: 8979-8993.

38. El-Sersy NA. 2012. Plackett-Burman design to optimize biosurfactant production by marine Bacillus subtilis N10. Rom. Biotechnol. Lett. 17: 7049-7064.

39. Prieto L, Michelon M, Burkert J, Kalil S, Burkert C. 2008. The production of rhamnolipid by a Pseudomonas aeruginosa strain isolated from a southern coastal zone in Brazil. Chemosphere 71: 1781-1785.

40. Gudiña EJ, Teixeira JA, Rodrigues LR. 2016. Biosurfactants produced by marine microorganisms with therapeutic applications. Mar. Drugs 14: 38.

41. Rufino RD, Sarubbo LA, Neto BB, Campos-Takaki GM. 2008. Experimental design for the production of tensio-active agent by Candida lipolytica. J. Ind. Microbiol. Biotechnol. 35: 907-914.

42. Thavasi R, Jayalakshmi S, Banat IM. 2011. Application of biosurfactant produced from peanut oil cake by Lactobacillus delbrueckii in biodegradation of crude oil. Bioresour. Technol. 102: 33663372.

43. Luna JM, Rufino RD, Sarubbo LA, Campos-Takaki GM. 2013. Characterisation, surface properties and biological activity of a biosurfactant produced from industrial waste by Candida sphaerica UCP0995 for application in the petroleum industry. Colloids Surf. B Biointerfaces 102: 202-209.

44. Santos A, Silva M, Costa E, Rufino R, Santos V, Ramos C, et al. 2018. Production and characterization of a biosurfactant produced by Streptomyces sp. DPUA 1559 isolated from lichens of the Amazon region. Braz. J. Med. Biol. Res. 51: e6657.

45. Santos E, Teixeira M, Converti A, Porto A, Sarubbo L. 2019. Production of a new lipoprotein biosurfactant by Streptomyces sp. DPUA1566 isolated from lichens collected in the Brazilian Amazon using agroindustry wastes. Biocatal. Agric. Biotechnol. 17: 142-150.

46. Rangarajan V, Sen R. 2013. An inexpensive strategy for facilitated recovery of metals and fermentation products by foam fractionation process. Colloids Surf. B Biointerfaces 104: 99-106.

47. Pereira F, Almeida JR, Paulino M, Grilo IR, Macedo H, Cunha I, et al. 2020. Antifouling napyradiomycins from marine-derived Actinomycetes Streptomyces aculeolatus. Mar. Drugs 18: 63. 